\title{
DYNAMICS OF MICROARTROPOD ABUNDANCE IN CHERNOZEM TYPICAL OF DIFFERENT FARMING SYSTEMS IN THE CONDITIONS OF THE LEFT BANK OF THE FOREST-STEPPE OF UKRAINE
}

\section{Serhii Rieznik $^{1}$}

DOI: https://doi.org/10.30525/978-9934-588-11-2_7

Introduction. Due to the problems of changes in biogeocenotic cover due to anthropogenic activity, the question arises about changes occurring in arable soils at the present stage of soil formation, their characteristics and diagnostic features. Soil invertebrates, as a structural element of ecosystems, play an important role in the processes of transformation of matter and energy. Ground animals are part of complex food chains, sometimes containing several trophic levels. Since most soil invertebrates are saprophages, the greater the number and diversity of groups, the more efficient they are in the work of the destruction of dead plant residues, thereby contributing to the supply of microorganisms with nutrients and available organic matter. It is also worth remembering that with the active involvement of animals and insects, the decomposition of organic residues is much faster than without them, since they grind up organic residues thereby increasing the reaction area and are carriers of microorganisms, and cause the change of the fungal phase of decomposition into microbial [1, p. 96-106; 2, p. $125-127 ; 3$, p. 5-11]. Analyzing the qualitative and quantitative characteristics of invertebrate communities, it is possible to determine the effectiveness of functioning of different ecosystems, to predict their development and to draw conclusions about the use of their ecological potential [4; 5, p. 66-76]. This is important for determining the magnitude of anthropogenic changes in modern biogeocenosis and finding ways to optimally use land in Ukraine. Therefore, the study of the composition and abundance of small arthropods (microarthropods) in chernozem typical is important for understanding and studying the development of chernozem soils.

Objects and research methods. Chornozems typical of the forest-steppe of Ukraine within the Zinkiv district of Poltava region were studied. Individual soil samples were selected from farms operating under two radically different farming systems, in particular PE «Agroecology» of Shishatsky district, Poltava region where own model of organic agriculture is created, based on surface tillage and widespread use of various organic fertilizers, and LLC «Burat Agro» of Zinkiv district of Poltava region where used system of various-depth tillage and plant protection products of the best domestic and foreign producers. The following options were selected for the studies: 1) corn for grain (intensive farming system), 2) corn for grain (organic farming system), 3) winter wheat (organic farming system), 4) fallow (over 20 years without cultivation). Sampling $(0-10,10-20,20-30,30-40 \mathrm{~cm})$ was carried out in the first decade of May, August and November by the method of cutting ring by

\footnotetext{
${ }^{1}$ Kharkiv National Agrarian University named after V.V. Dokuchayev, Ukraine ORCID: https://orcid.org/0000-0002-2703-1021
} 
N. A. Kachinsky cylinders. Catch of springtails and oribatide samples was performed in simple Tulgren funnels, followed by their fixation in aqueous-alcohol solution with the addition of $3 \%$ glycerol. The amount of microarthropods was recalculated by 1 $\mathrm{dm}^{3}$ in the corresponding soil layer [6, p. 163-174; 7].

Results and discussion. Based on the analysis of the obtained data, Fig. 1-5 it should be noted that, with depth, the number of microarthropods decreases. In addition to the option of corn for grain grown under an intensive farming system, where there is an increase in their numbers at a depth of $20-30 \mathrm{~cm}$. This is a clear sign of the use of plowing in the soil tillage system, which results in plowing of crop residues and redistribution of microartropods by depth. It should also be noted that in the variant of the fallow, the highest values of the number of springtails and the mites were recorded. Conversely, the variants of agrogenic use showed the lowest indices of springtails and the highest - oribatide.

Regarding the spread of microarthropods by profile, it should be noted that their largest numbers were recorded in the most rich organic horizons. That is, with depth, usually their number decreases. This pattern is especially clear in the autumn in the corn grain variant (intensive farming system), where the outbreak of numbers was recorded in a layer of $20-30 \mathrm{~cm}$ where there were freshly plowed plant residues. We note a decrease in the number of microartropods in the layer of $0-10 \mathrm{~cm}$ in the variants of the agricultural use of soils in the spring and autumn, which is caused by the drying of this layer of soil as a result of cultivation of soil tillage units. This trend is absent in fallow and winter wheat (organic farming) variants.

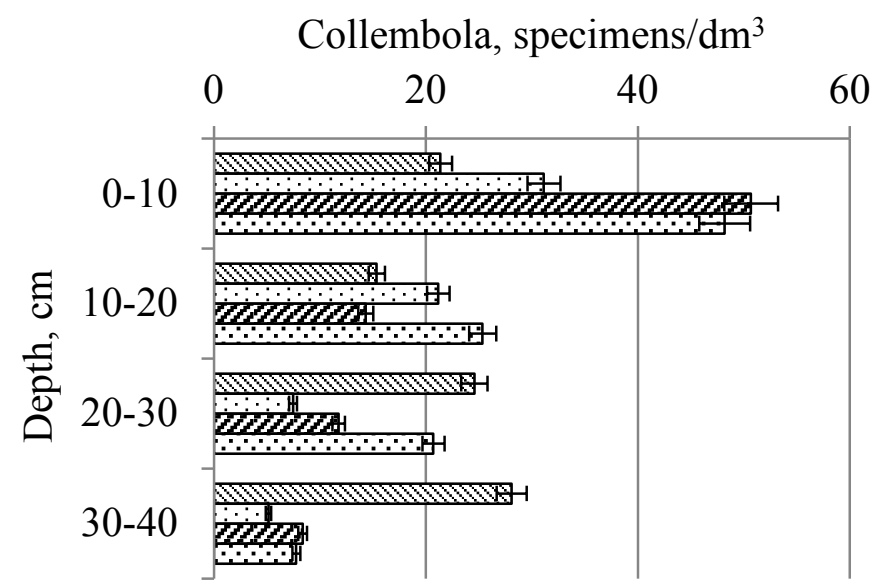

60
⿶ corn for grain (intensive farming system)
$\square$ corn for grain (organic farming system)
Ð winter wheat (organic farming system)
fallow

\section{Figure 1. The average annual number of springtails at depths, specimens $/ \mathrm{dm}^{3}$}

Having analyzed data of fig. 1-2 it should be noted that, the average annual number of microarthropods ranged from 21-51 specimens $/ \mathrm{dm}^{3}$ springtails and $38-221$ specimens $/ \mathrm{dm}^{3}$ oribatides in the layer $0-10 \mathrm{~cm}$. But gradually decreased to 5-28 specimens $/ \mathrm{dm}^{3}$ springtails and 28-84 specimens $/ \mathrm{dm}^{3}$ oribatides in the layer of $30-40 \mathrm{~cm}$. The maximum number of springtails is found in the variant of winter wheat 51 specimens $/ \mathrm{dm}^{3}$ in the layer of $0-10 \mathrm{~cm}$, and the minimum in the variant of corn for grain (organic farming system) 5 specimens $/ \mathrm{dm}^{3}$ in the layer of $30-40 \mathrm{~cm}$. 


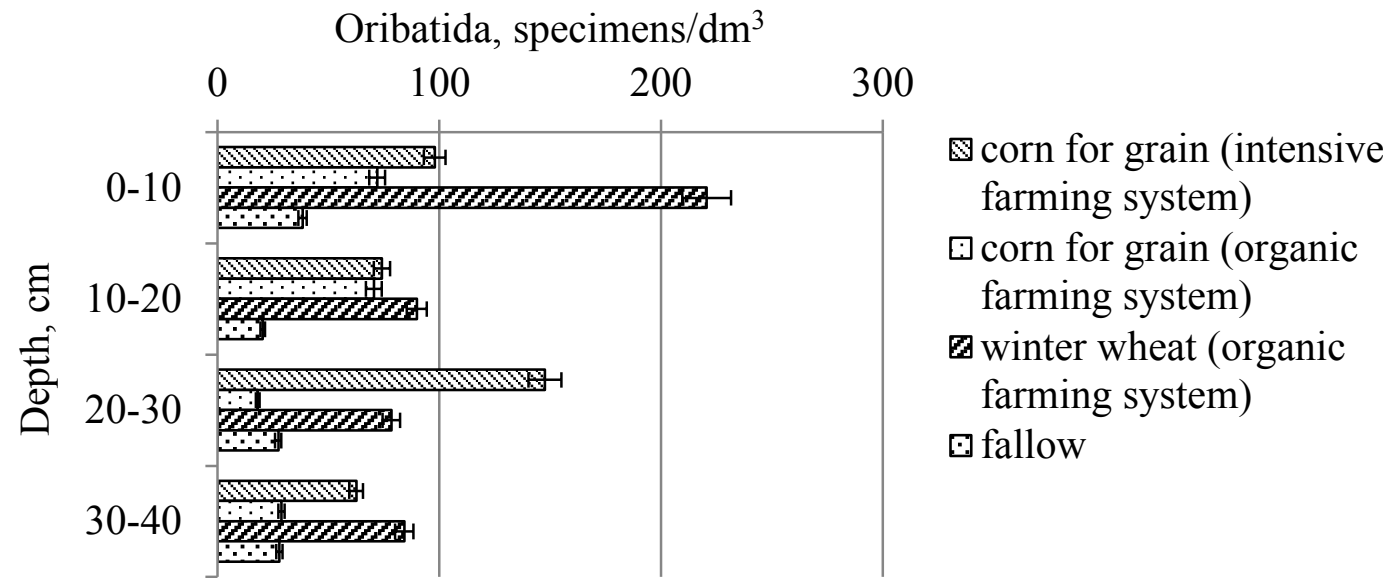

Figure 2. The average annual number of Oribatid mites at depths, specimens $/ \mathbf{d m}^{3}$

These figures. 3 indicate that the highest number of springtails in the layer of $0-40 \mathrm{~cm}$ was recorded in the summer in the overgrowth of $47 \mathrm{specimens} / \mathrm{dm}^{3}$, and the smallest - also in the summer but in the variant of corn for grain (organic farming system) 6 specimens $/ \mathrm{dm}^{3}$. The maximum number of springtails in corn variants for grain in the autumn and is 39 specimens $/ \mathrm{dm}^{3}$ at growing corn under intensive farming and 30 specimens $/ \mathrm{dm}^{3}$ at organic farming. In the variant of winter wheat grown by on the organic farming system, there was a slight fluctuation in the number of springtails over the seasons.

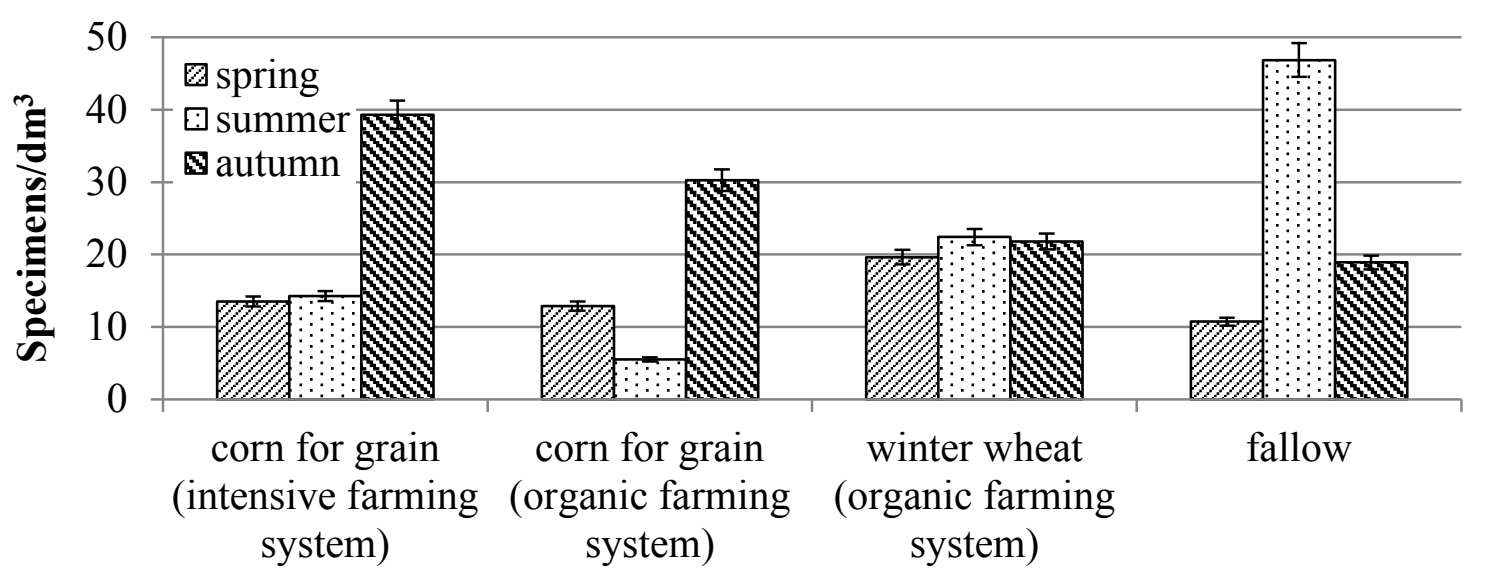

Figure 3. The number of springtails in the layer $0-40 \mathrm{~cm}$ by seasons, specimens $/ \mathbf{d m}^{3}$

We note an increase in the number of oribatides in soils of agrogenic use, but with similar trends in seasonal dynamics (Figure 4). Maximum values of the number of mites were recorded in summer in the variant of winter wheat (organic farming) 173 specimens $/ \mathrm{dm}^{3}$, and the minimum in the summer in variants of corn (organic farming) 17 specimens $/ \mathrm{dm}^{3}$ and fallow 18 specimens $/ \mathrm{dm}^{3}$. 


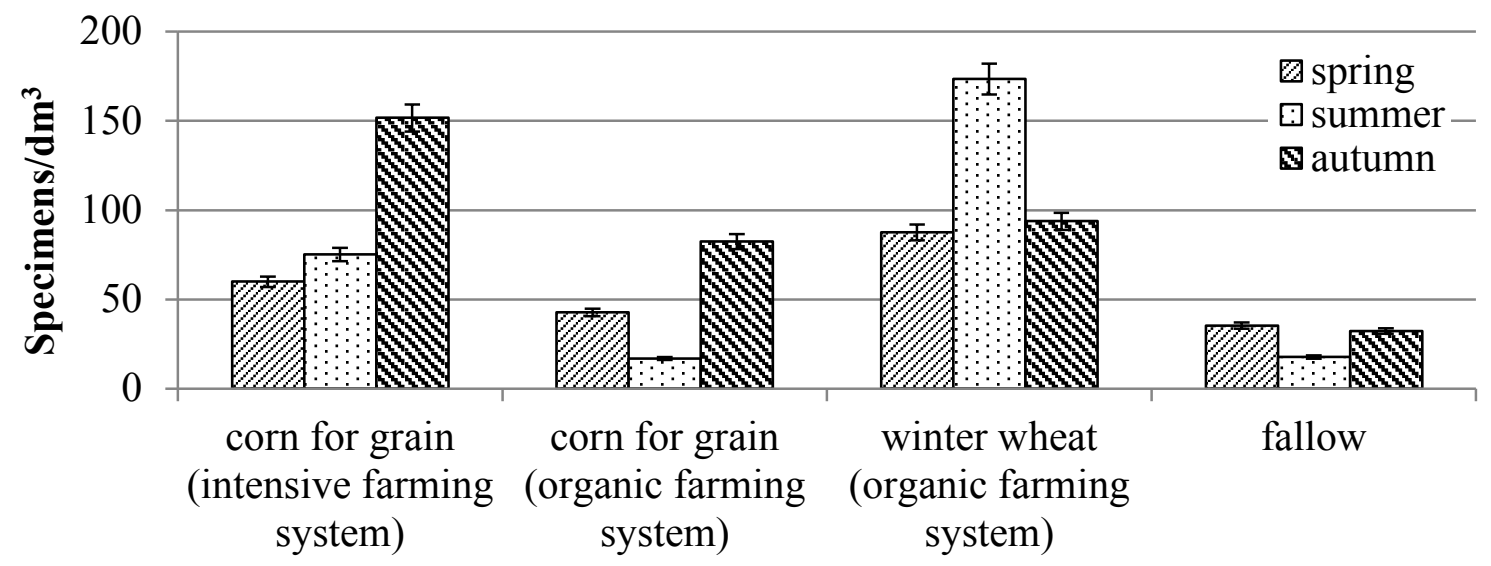

\section{Figure 4. The number of Oribatid mites in the layer of $0-40 \mathrm{~cm}$ by seasons, specimens $/ \mathbf{d m}^{3}$}

Conclusions. Agrogenic use causes an increase in the number of oribatides while reducing the population of springtails. Prolonged fallow use has led to the formation of more stable populations with smaller variations in their numbers by season and a more even distribution in the $\mathrm{H}$ (A) horizon. The use of siderates in the crop rotation link contributes to the increase in the total number of microarthropods, especially oribatide. As the impact of different farming systems and fertilizers on the microartopods has been poorly studied, further studies are relevant to uncovering the direction of biological processes under the conditions of the agrogenic use of chernozem soils.

\section{References:}

1. David C. Coleman, Mac A. Callaham, Jr. and D.A. Crossley, Jr. (2018). Fundamentals of Soil Ecology. Academic Press is an imprint of Elsevier, pp. 96-106.

2. Eldor A. Paul (2015). Soil Microbiology, Ecology, and Biochemistry, Academic Press is an imprint of Elsevier, pp. 125-127.

3. Striganova B. R., Kozlovskaya L. S. (1985). Sovremennye aspekty izucheniya protsessov razlozheniya rastitel'nykh ostatkov $\mathrm{v}$ pochve [Modern aspects of studying the processes of decomposition of plant residues in soil]. Razlozhenie rastitel'nykh ostatkov $\mathrm{v}$ pochve [Decomposition of plant residues in soil], Moscow: Science, pp. 5-11.

4. Uffe N. Nielsen (2019). Soil Fauna Assemblages: Global to Local Scales, Cambridge University Press, $351 \mathrm{p}$.

5. Rieznik S. V., Novosad K. B., Gavva D. V., Sotnykov Yu. O. (2015). Microarthropod population dynamics in chornozems (black soils) typical under the different agrogene and postagrogene use. Bulletin of Kharkiv national agrarian university named after V. V. Dokuchayev, Seria «Soil science, agrochemistry, farming, forestry, ecology of soil»», Kharkiv: KhNAU, no. 2, pp. 66-76.

6. Bater, J. E. (1996). Micro- and Macro-arthropods. In: Hall, G.S. (Ed.), Methods for the Examination of Organismal Diversity in Soils and Sediments. CAB International, New York, pp. 163-174.

7. Gilyarov M. S. (1975). Uchet melkikh chlenistonogikh (mikrofauny) i nematode [Accounting for small arthropods (microfauna) and nematodes]. Metody pochvenno-zoologicheskikh issledovaniy [Methods of soil-zoological research]. Moscow: Science. 